\title{
Application of cotton straw biochar and compound Bacillus biofertilizer decrease the bioavailability of soil cd through impacting soil bacteria
}

\author{
Yongqi Zhu, Xin LV, Jianghui Song, Weidi Li and Haijiang Wang ${ }^{*}$
}

\begin{abstract}
Background: Cd seriously threatens soil environment, remedying $\mathrm{Cd}$ in farmland and clearing the response of soil environment to modifiers in Cd-contaminated soils is necessary. In this study, the effects of cotton straw biochar and compound Bacillus biofertilizer used as modifiers on the biochemical properties, enzyme activity, and microbial diversity in $\mathrm{Cd}$-contaminated soils $\left(1,2\right.$, and $\left.4 \mathrm{mg} \cdot \mathrm{kg}^{-1}\right)$ were investigated.

Results: The results showed that both cotton straw biochar and compound Bacillus biofertilizer could improve the soil chemical characteristics, including the increase of soil $\mathrm{C} / \mathrm{N}$ ratio, electrical conductance $(\mathrm{EC})$ and $\mathrm{pH}$, and the most important decrease of soil available $C d$ content by $60.24 \%$ and $74.34 \%$, respectively $(P<0.05)$. On the other hand, adding cotton straw biochar and compound Bacillus biofertilizer in Cd stressed soil also improved soil biological characteristics. Among them, cotton straw biochar mainly through increasing soil alkaline phosphatase activity and improve bacteria abundance, compound Bacillus biofertilizer by increasing soil invertase, alkaline phosphatase, catalase, and urease activity increased bacterial community diversity. On the whole, the decrease of soil available Cd was mainly caused by the increase of soil $\mathrm{pH}, \mathrm{C} / \mathrm{N}$, urease and alkaline phosphatase activities, and the relative abundance of Acidobacteria and Proteobacteria.
\end{abstract}

Conclusions: In summary, the applications of cotton straw biochar and compound Bacillus biofertilizer could decrease soil available $\mathrm{Cd}$ concentration, increase soil bacterial community diversity and functions metabolism, and reduce the damage of $\mathrm{Cd}$ stress, compared with cotton straw biochar, compound Bacillus biofertilizer was more effective in immobilizing $\mathrm{Cd}$ and improving soil environmental quality.

Keywords: Bacteria diversity, Biochar, Biofertilizer, Cd bioavailability, Enzyme activity

\section{Background}

Cd contamination caused by sewage irrigation and application of fertilizers and pesticides is very common in the farmlands in China [1-3]. Higher $\mathrm{Cd}$ accumulation negatively impacts soil biochemical properties [4-6] and

*Correspondence: wanghaijiang@shzu.edu.cn

Agricultural College, Shihezi University, 832003 Shihezi, Xinjiang, P. R. China microbial activity [7]. However, soil enzymes play important role in various biochemical processes. When the soil is contaminated by Cd, soil urease, phosphatase, and catalase activities are obviously decreased [8]. For example, Wang et al. [9] have shown that the phosphatase activity in Cd-contaminated soil $\left(10 \mathrm{mg} \cdot \mathrm{kg}^{-1}\right)$ could be obviously decreased, while no difference could be found in the urease activity. Moreover, soil microbes, an essential part of the ecosystem, are also greatly impacted by Cd contamination [10]. Fritze [11] has shown that the 
number of Actinomycetes and fungi could be decreased in Cd-treated soil. Cd mainly accumulates in the surface soil. Higher $\mathrm{Cd}$ accumulation always decreases the activities of microbes through damaging the cell membranes and DNA structure and influencing cell functions [12-14], and causes toxicity to microbes. Therefore, for Cd-contaminated soils, it is indispensable to find an ecofriendly remediation method to improve the degraded soil ecosystem.

Biotic and abiotic remediation are important methods for the remediation of heavy metal-contaminated soils [15]. Abiotic remediation includes electro kinetic remediation, soil replacement, soil isolation, chemical leaching, organic matter fixation, etc. [15]. Biochar is an environmentally friendly adsorbent that could be used for abiotic remediation, with the characteristics of low cost and high efficiency [16]. It could reduce soil available Cd concentration [17], and increase soil $\mathrm{pH}[16,18]$, organic carbon concentration [19], enzyme activity [20], and biochemical properties. Bioremediation uses microorganisms or plants to detoxify heavy metals or remove from soils. Compound Bacillus biofertilizer, an atoxic multifunctional fertilizer, could be used in the inoculation with functional bacteria to enhance soil fertility and quality, and reduce heavy metal toxicity [21]. Previous study has reported that the Cd-removal rate after inoculating with Bacillus in soil reached more than $80.01 \%$, and the adsorption capacity was $62.0-159.5 \mathrm{mg} \mathrm{Cd}$ [22]. Moreover, the application of modifiers is certain to impact soil microbes and enzyme activity. Chen et al. [23] have shown that the application of biochar $\left(40 \mathrm{t} \mathrm{ha}^{-1}\right)$ could increase phosphatase and catalase activities, and change the microbial biomass by changing soil carbon and nitrogen. In the remediation of $\mathrm{Pb}$ - and As-contaminated soils using biochar, the relative abundance of Actinomycetes could be increased obviously, while the relative abundances of Acidbacteria and Chloroflexi were decreased [24]; however, the urease activity could be increased obviously after application of compound Bacillus biofertilizer [25]. The planting area of cotton in China is as high as $3339.2 \mathrm{kha}$ in 2019 , accounting for $9.98 \%$ of the total area of cotton fields in the world. The planting area of cotton in Xinjiang Province is up to 2540.5 kha, accounting for $70.03 \%$ of the total area in China. In recent years, due to the rapid development of industry and unreasonable field management, such as excessive application of chemical fertilizer, pesticides and plastic film residues, the potential ecological risk of soil Cd contamination in farmlands increases rapidly in Xinjiang, China [26, 27].

At present, the researches on the remediation of $\mathrm{Cd}$ contaminated soil are mostly based on acidic soil, while there are few reports based on alkaline soil in arid and semi-arid areas. Besides, biochar and biofertilizer are commonly used in soil remediation, but the mechanisms of the remediation of $\mathrm{Cd}$ contaminated alkaline soil by the application of biochar and biofertilizer are still not clear. Therefore, in this study, cotton straw biochar and compound Bacillus biofertilizer were selected as modifiers to explore their effects on the diversity of bacterial communities in $\mathrm{Cd}$-contaminated alkaline soils, and clarify the key bacteria involved in the remediation. We hypothesized that: (1) There may be differences in the biochemical characteristics and microbial diversity of alkaline soil contaminated by different concentrations of Cd; and (2) Applications of cotton straw biochar and compound Bacillus biofertilizer may change soil enzyme activity and bacterial diversity and have different effects on the key bacterial communities in the soil.

\section{Results}

\section{Soil biochemical properties}

The applications of cotton straw biochar and compound Bacillus biofertilizer had different effects on soil biochemical properties (Table 1). After the application of $\mathrm{Cd}$, the soil $\mathrm{C} / \mathrm{N}$ ratios in the $\mathrm{H} 1 \mathrm{~T}, \mathrm{H} 2 \mathrm{~T}$, and $\mathrm{H} 3 \mathrm{~T}$ treatments decreased by $3.91 \%, 7.31 \%$, and $14.55 \%$, respectively, while the soil EC increased by $90.38 \%, 61.54 \%$, and $28.85 \%$, respectively $(P<0.05)$, compared with those in the control group (H0T treatment).

Table 1 Effect of the applications of biochar and biofertilizer on soil biochemical properties

\begin{tabular}{|c|c|c|c|c|}
\hline $\begin{array}{l}\mathrm{Cd} \\
\left(\mathrm{mg} \cdot \mathrm{kg}^{-1}\right)\end{array}$ & Modifiers(\%) & $\mathrm{pH}$ & $\mathrm{C} / \mathrm{N}$ ratio & $\begin{array}{l}\mathrm{EC} \\
\left(\mathrm{ms} \cdot \mathrm{cm}^{-1}\right)\end{array}$ \\
\hline \multirow[t]{3}{*}{ HO } & T & $7.44 \pm 0.21 b$ & $10.54 \pm 0.39 d$ & $2.08 \pm 0.02 \mathrm{~h}$ \\
\hline & B & $8.49 \pm 0.24 \mathrm{a}$ & $16.93 \pm 0.78 b c$ & $2.88 \pm 0.02$ ef \\
\hline & J & $8.42 \pm 0.24 \mathrm{a}$ & $18.51 \pm 0.53 \mathrm{a}$ & $2.41 \pm 0.02 \mathrm{~g}$ \\
\hline \multirow[t]{3}{*}{$\mathrm{H} 1$} & $\mathrm{~T}$ & $7.23 \pm 0.20 b$ & $9.60 \pm 0.38 d$ & $3.96 \pm 0.03 b$ \\
\hline & B & $8.58 \pm 0.25 \mathrm{a}$ & $16.41 \pm 0.62 c$ & $4.91 \pm 0.04 \mathrm{a}$ \\
\hline & J & $8.57 \pm 0.24 a$ & $\begin{array}{l}17.62 \pm 0.48 \\
a b c\end{array}$ & $4.96 \pm 0.04 \mathrm{a}$ \\
\hline \multirow[t]{3}{*}{$\mathrm{H} 2$} & $\mathrm{~T}$ & $7.97 \pm 0.23 \mathrm{ab}$ & $10.55 \pm 0.36 d$ & $3.36 \pm 0.03 c$ \\
\hline & B & $8.63 \pm 0.24 \mathrm{a}$ & $16.47 \pm 0.54 \mathrm{c}$ & $4.88 \pm 0.04 \mathrm{a}$ \\
\hline & J & $8.45 \pm 0.24 \mathrm{a}$ & $18.66 \pm 0.48 \mathrm{a}$ & $4.77 \pm 0.04 \mathrm{a}$ \\
\hline \multirow[t]{3}{*}{$\mathrm{H} 3$} & $\mathrm{~T}$ & $7.56 \pm 0.21 b$ & $9.57 \pm 0.33 \mathrm{~d}$ & $2.68 \pm 0.02 \mathrm{gf}$ \\
\hline & B & $8.46 \pm 0.21 \mathrm{a}$ & $16.92 \pm 0.51 b c$ & $3.30 \pm 0.03 \mathrm{~cd}$ \\
\hline & J & $8.57 \pm 0.24 \mathrm{a}$ & $17.98 \pm 0.40 \mathrm{ab}$ & $3.03 \pm 0.05 \mathrm{de}$ \\
\hline \multicolumn{5}{|c|}{ Regression Analysis } \\
\hline $\mathrm{H}$ & & ns & ns & ns \\
\hline BJ & & ns & $*$ & ns \\
\hline $\mathrm{B} J^{*} \mathrm{H}$ & & ns & * & ns \\
\hline
\end{tabular}

T, no modifiers; B, $3 \%$ biochar was applied; J, $1.5 \%$ biofertilizer was applied; $\mathrm{HO}$, no $\mathrm{Cd} ; \mathrm{H} 1,1 \mathrm{mg} \cdot \mathrm{kg}^{-1}$ of $\mathrm{Cd}$ was applied; $\mathrm{H2}, 2 \mathrm{mg} \cdot \mathrm{kg}^{-1}$ of $\mathrm{Cd}$ was applied; $\mathrm{H} 3$, $4 \mathrm{mg} \cdot \mathrm{kg}^{-1}$ of Cd was applied. Different lowercase letters in the same column indicate significant differences $(P<0.05)$. ${ }^{*}, P<0.01 ; *, 0.01<P<0.05 ; \mathrm{ns}, P \geq$ 0.05 


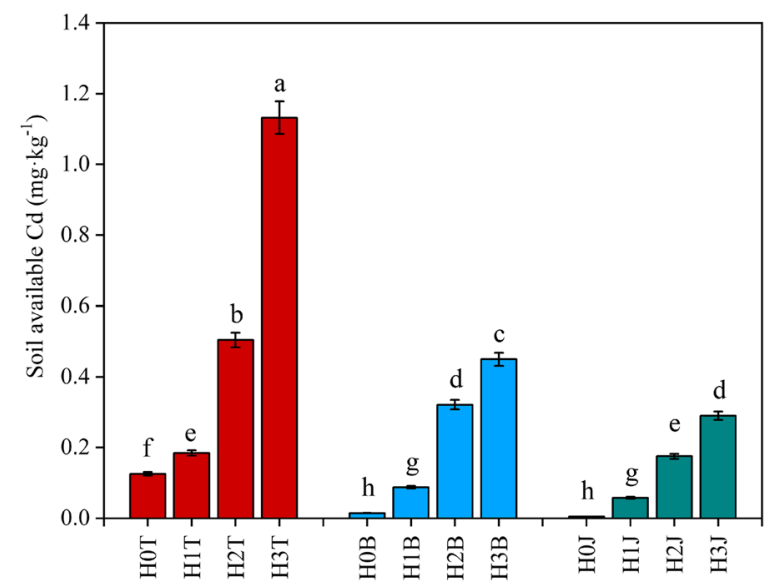

Fig. 1 Effect of the applications of cotton straw biochar and compound Bacillus biofertilizer on soil available $\mathrm{Cd}$. Values show the mean of five replicates \pm SE. Means followed by same small letters are not significant different at $P<0.05$ by using the Duncan test

The soil $\mathrm{pH}, \mathrm{C} / \mathrm{N}$ ratio, and $\mathrm{EC}$ could be increased after the applications of cotton straw biochar and compound Bacillus biofertilizer (Table 1 ). The soil $\mathrm{C} / \mathrm{N}$ ratio and $\mathrm{EC}$ in the cotton straw biochar and compound Bacillus biofertilizer treatments were higher than those in the control group. For example, soil $\mathrm{pH}, \mathrm{C} / \mathrm{N}$ ratio, and $\mathrm{EC}$ in the $\mathrm{H} 2 \mathrm{~B}$ treatment increased by $10.78 \%, 56.11 \%$, and $45.24 \%$, respectively, and those in the H2J treatment increased by $6.02 \%, 76.87 \%$, and $41.96 \%$, respectively, compared with those in the H2T treatment $(P<0.05)$.

Regression analysis showed that the application of $\mathrm{Cd}$ had no effect on soil $\mathrm{pH}, \mathrm{C} / \mathrm{N}$ ratio, and $\mathrm{EC}(P>$ $0.05)$, and the application of modifiers greatly impacted soil $\mathrm{C} / \mathrm{N}$ ratio $(P<0.05)$. The modifiers and $\mathrm{Cd}$ greatly impacted soil $\mathrm{C} / \mathrm{N}$ ratio $(P<0.05)$, but no differences were found in soil $\mathrm{pH}$ and $\mathrm{EC}(P>0.05)$.

\section{Effects of cotton straw biochar and compound Bacillus biofertilizer on soil available $\mathrm{Cd}$}

The soil available $\mathrm{Cd}$ concentration in the H1T, H2T, and H3T treatments increased after the application of exogenous $\mathrm{Cd}(P<0.05)$ (Fig. 1$)$. The highest soil available Cd concentration was $1.13 \mathrm{mg} \cdot \mathrm{kg}^{-1}$ which was found in the H3T treatment. The soil available $\mathrm{Cd}$ concentration decreased in the cotton straw biochar $(\mathrm{H} 1 \mathrm{~B}, \mathrm{H} 2 \mathrm{~B}$, and $\mathrm{H} 3 \mathrm{~B}$ ) and compound Bacillus biofertilizer (H1J, H2J, and H3J) treatments $(P<0.05)$. Soil available $\mathrm{Cd}$ concentration in the HOB and HOJ treatments decreased by $88.26 \%$ and $95.96 \%$, respectively $(P<0.05)$, compared with that in the H0T treatment. Soil available Cd concentration in the $\mathrm{H} 1 \mathrm{~B}$ and $\mathrm{H} 1 \mathrm{~J}$ treatments decreased by $52.32 \%$ and $68.54 \%$, respectively $(P<0.05)$, compared with that in the H1T treatment. Soil available Cd concentration in the $\mathrm{H} 2 \mathrm{~B}$ and $\mathrm{H} 2 \mathrm{~J}$ treatments decreased by $36.30 \%$ and $65.17 \%$, respectively $(P<0.05)$, compared with that in the $\mathrm{H} 2 \mathrm{~T}$ treatment. Soil available $\mathrm{Cd}$ concentration in the $\mathrm{H} 3 \mathrm{~B}$ and $\mathrm{H} 3 \mathrm{~J}$ treatments decreased by $60.24 \%$ and $74.34 \%$, respectively $(P<0.05)$, compared with that in the H3T treatment.

\section{Effects of modifiers and Cd on soil enzyme activities}

Soil enzyme activity decreased after the application of exogenous Cd (Fig. 2). Soil invertase activity in the H1T, H2T, and H3T treatments decreased by $18.36 \%, 37.25 \%$, and 45.07, respectively $(P<0.05)$, compared with that in the HOT treatment. Soil alkaline phosphatase activity (ALP) in the H2T and H3T treatments decreased by $7.21 \%$ and $35.53 \%$, respectively $(P<0.05)$, and soil urease activity decreased by $18.54 \%$ and $27.33 \%$, respectively $(P<0.05)$, compared with those in the HOT treatment. The activities of soil invertase, alkaline phosphatase, catalase, and urease in the H3T treatment were the lowest, which decreased by $45.07 \%, 35.53 \%, 68.01 \%$, and $27.33 \%$, respectively $(P<$ 0.05), compared with those in the H0T treatment.

Soil invertase enzyme activity increased after the applications of cotton straw biochar and compound Bacillus biofertilizer (Fig. 2 A). Soil invertase activity in the H1B and H1J treatments increased by $17.51 \%$ and $61.29 \%$, respectively, compared with that in the H1T treatment $(P<0.05)$. The activity of alkaline phosphatase also increased after the applications of cotton straw biochar and compound Bacillus biofertilizer, and difference was found between cotton straw biochar and compound Bacillus biofertilizer treatments $(P<0.05)$. For example, soil alkaline phosphatase activity in the H3B and H3J treatments increased by $16.16 \%$ and $43.74 \%$, respectively $(P<0.05)$, compared with that in the H3T treatment (Fig. 2B). Soil catalase activity in the $\mathrm{H} 1 \mathrm{~B}$ and $\mathrm{H} 1 \mathrm{~J}$ treatments increased by $23.08 \%$ and $53.85 \%$, respectively $(P<0.05)$, compared with that in the $\mathrm{H} 1 \mathrm{~T}$ treatment (Fig. 2 C). Soil urease activity in the H2B and H2J treatments increased by $13.27 \%$ and $28.94 \%$, respectively $(P$ $<0.05$ ), compared with that in the H2T treatment (Fig. 2D).

\section{Effects of the applications of cotton straw biochar and compound Bacillus biofertilizer on soil microbial community diversity}

Coverage indices showed that the sequencing coverage indices of each sample was more than $97.97 \%$, which could reflect the reliability of this sequencing result (Table 2). The Simpson index increased after the applications of cotton straw biochar and compound Bacillus biofertilizer $(P<0.05)$. The Simpson's diversity index in the $\mathrm{H} 2 \mathrm{~B}$ and $\mathrm{H} 2 \mathrm{~J}$ treatments increased by $66.67 \%$ and $50.88 \%$, respectively $(P<0.05)$, compared with that in the H2T treatment. The Chaol index in the cotton straw 

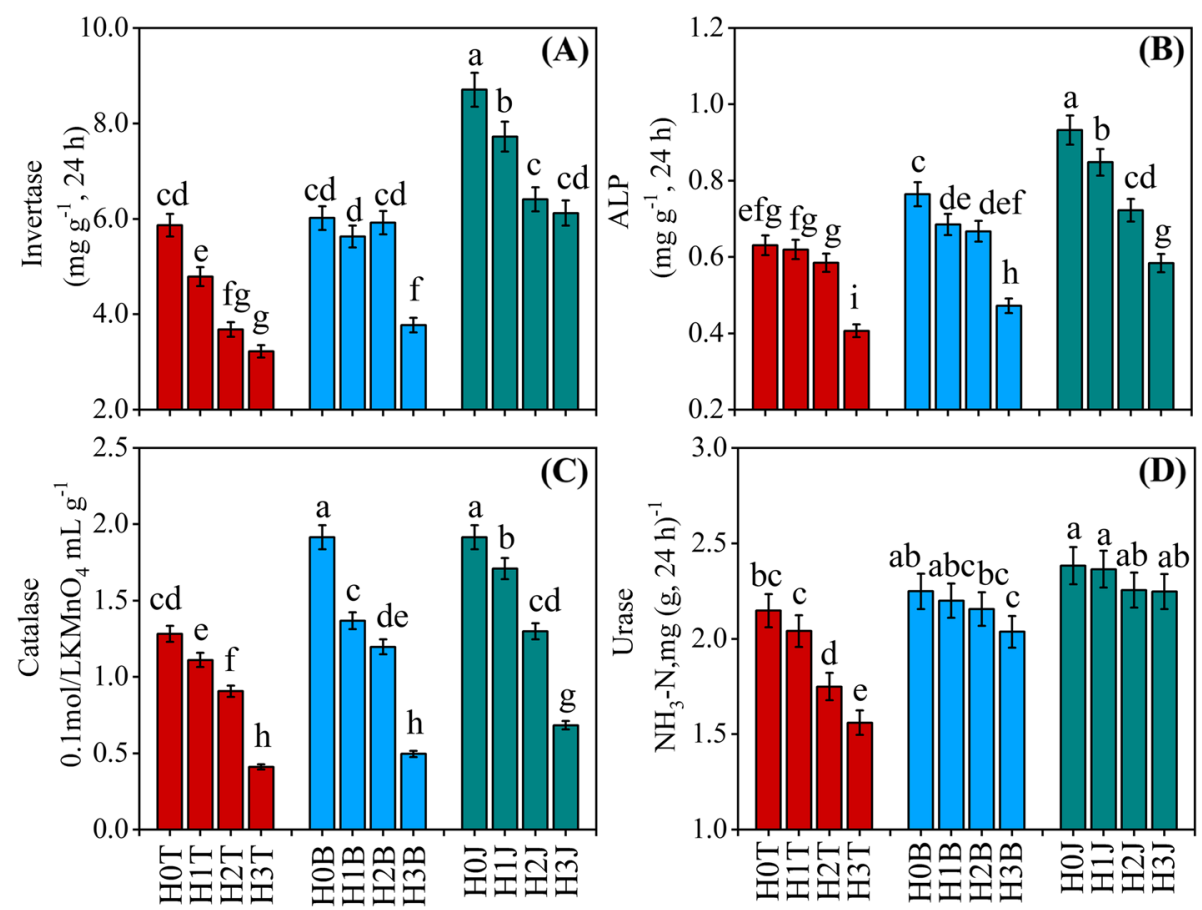

Fig. 2 Effect of the applications of cotton straw biochar and compound Bacillus biofertilizer on soil invertase (A), urease (B), alkaline phosphatase $(\mathbf{C})$, and catalase (D) activities. Values show the mean of five replicates \pm SE. Means followed by same small letters are not significant different at $P<$ 0.05 by using the Duncan test

biochar and compound Bacillus biofertilizer treatments increased. The Chao1 index in the HOB and HOJ treatments increased by $20.21 \%$ and $17.66 \%$, respectively $(P<$ 0.05), compared with that in the HOT treatment; similar trends were also found in the H3B and H3J treatments.

Regression analysis showed that $\mathrm{Cd}$ and modifiers greatly impacted Chaol index and Coverage index $(P<$ $0.05)$, but there was no difference in the Simpson's diversity index $(P>0.05)$. Moreover, the applications of $\mathrm{Cd}$ and modifiers had a combined effect on soil microbial diversity $(P<0.05)$.

\section{Effect of the applications of cotton straw biochar and compound Bacillus biofertilizer on the relative abundance of soil bacteria}

According to the PLS-DA analysis, it can be seen that the composition of soil bacterial community in $\mathrm{Cd}$ pollution treatment (Control) and modifier (cotton straw biochar and compound Bacillus biofertilizer) is significantly different on the COMP1 axis. There were significant differences between cotton straw biochar and compound Bacillus biofertilizer treatments on the COMP2 axis (Fig. 3 A). The applications of modifiers and $\mathrm{Cd}$ could obviously impact the relative abundance of bacteria. Among them, Acidobacteria, Proteobacteria, Chloroflexi, Gemmatimonadetes, Bacteroidetes, and Actinobacteria were the dominant phyla, accounting for $91.27-95.52 \%$ of bacteria in soil samples (Fig. $3 \mathrm{C}$ ). Ternary phase diagram analysis showed that the composition and distribution ratio of phylum level were different in different samples. Chloroflexi was abundant in the control treatments (H0T, H1T, H2T, H3T). Acidobacteria is more abundant in the cotton straw biochar treatments $(\mathrm{HOB}, \mathrm{H} 1 \mathrm{~B}, \mathrm{H} 2 \mathrm{~B}$, H3B) and compound Bacillus biofertilizer treatments (H0J, H1J, H2J, H3J) (Fig. 3B). For the control treatments (H0T, H1T, H2T, H3T), cotton straw biochar treatments (H0B, H1B, H2B, H3B), and compound Bacillus biofertilizer treatments (H0J, H1J, H2J, H3J) samples were tested for significant difference between groups, the results showed that compared with the control treatments (H0T, H1T, H2T, H3T), Acidobacteria, Gemmatimonadetes and Bacteroidetes increased in the cotton straw biochar treatments (H0B, H1B, H2B, H3B) $(P \geq 0.1)$, Proteobacteria, Chloroflexi, Actinobacteria decreased $(P \geq 0.1)$; Compared with the control treatments (HOT, H1T, H2T, H3T), Acidobacteria, Gemmatimonadetes, and Actinobacteria increase $(P \geq 0.1)$ in the compound Bacillus biofertilizer treatments (H0J, H1J, H2J, H3J). Proteobacteria, Chloroflexi and Bacteroidetes decreased $(P \geq 0.1)$ (Fig. 4).

The relative abundance of Acidobacteria in the H1T and H3T treatments decreased by $10.77 \%$ and $14.92 \%$, 
Table 2 Changes in microbial diversity after the applications of biochar and biofertilizer

\begin{tabular}{|c|c|c|c|c|}
\hline \multirow{2}{*}{$\begin{array}{l}\mathrm{Cd} \\
\left(\mathrm{mg} \cdot \mathrm{kg}^{-1}\right)\end{array}$} & \multirow{2}{*}{$\begin{array}{l}\text { Modifiers } \\
\text { (\%) }\end{array}$} & \multicolumn{3}{|c|}{ Diversity index of soil microbial community } \\
\hline & & Simpson & Chao1 & Coverage \\
\hline \multirow[t]{3}{*}{$\mathrm{HO}$} & $\mathrm{T}$ & $0.0070 \pm 0.0002 f$ & $1801 \pm 51.99$ e & $0.9853 \pm 0.028 a$ \\
\hline & B & $0.0117 \pm 0.0003 c$ & $2165 \pm 62.48 \mathrm{bcd}$ & $0.9819 \pm 0.028 \mathrm{a}$ \\
\hline & J & $0.0095 \pm 0.0003 d$ & $2119 \pm 61.17 \mathrm{~cd}$ & $0.9820 \pm 0.028 a$ \\
\hline \multirow[t]{3}{*}{$\mathrm{H} 1$} & $\mathrm{~T}$ & $0.0059 \pm 0.0002 \mathrm{~g}$ & $1964 \pm 56.69$ de & $0.9835 \pm 0.028 a$ \\
\hline & B & $0.0070 \pm 0.0002 f$ & $2030 \pm 58.61 \mathrm{~d}$ & $0.9841 \pm 0.028 \mathrm{a}$ \\
\hline & J & $0.0128 \pm 0.0004 b$ & $2397 \pm 69.22 \mathrm{a}$ & $0.9809 \pm 0.028 a$ \\
\hline \multirow[t]{3}{*}{$\mathrm{H} 2$} & $\mathrm{~T}$ & $0.0057 \pm 0.0002 \mathrm{~g}$ & $2083 \pm 60.13 \mathrm{~cd}$ & $0.9824 \pm 0.028 a$ \\
\hline & B & $0.0095 \pm 0.0005 d$ & $2453 \pm 70.81 a$ & $0.9800 \pm 0.028 a$ \\
\hline & 」 & $0.0086 \pm 0.0004$ de & $2277 \pm 65.74 a b c$ & $0.9799 \pm 0.028 a$ \\
\hline \multirow[t]{3}{*}{$\mathrm{H} 3$} & T & $0.0078 \pm 0.0004$ ef & $2333 \pm 67.36 \mathrm{ab}$ & $0.9797 \pm 0.028 a$ \\
\hline & B & $0.0090 \pm 0.0003 \mathrm{~d}$ & $2251 \pm 64.99 a b c$ & $0.9811 \pm 0.028 a$ \\
\hline & J & $0.0315 \pm 0.0009 a$ & $2251 \pm 64.98 a b c$ & $0.9806 \pm 0.028 a$ \\
\hline \multicolumn{5}{|c|}{ Regression Analysis } \\
\hline \multicolumn{2}{|l|}{$\mathrm{H}$} & ns & * & $* *$ \\
\hline \multicolumn{2}{|l|}{ BJ } & ns & * & $* *$ \\
\hline \multicolumn{2}{|l|}{$B J^{*} H$} & ns & * & $* *$ \\
\hline
\end{tabular}

T, no application of modifiers; B, 3\% biochar was applied; J, 1.5\% biofertilizer was applied; $\mathrm{H} 0$, no application of $\mathrm{Cd} ; \mathrm{H} 1,1 \mathrm{mg} \cdot \mathrm{kg}^{-1}$ of $\mathrm{Cd}$ was applied; $\mathrm{H} 2$, $2 \mathrm{mg} \cdot \mathrm{kg}^{-1}$ of $\mathrm{Cd}$ was applied; $\mathrm{H3}, 4 \mathrm{mg} \cdot \mathrm{kg}^{-1}$ of $\mathrm{Cd}$ was applied. Different lowercase letters in the same column indicate significant differences $(P<0.05)$ in Cd content. ${ }^{* *}, P<0.01 ;{ }^{*}, 0.01<P<0.05 ; \mathrm{ns}, P \geq 0.05$

respectively, and the relative abundance of Chloroflexi decreased by $36.94 \%$ and $39.64 \%$, respectively, compared with those in the HOT treatment. However, the relative abundances of Acidobacteria and Gemmatimonadetes in the HOB treatment increased by $12.63 \%$ and $2.09 \%$, respectively, compared with those in the HOT treatment. Similar trends were found in the relative abundances of Acidobacteria and Gemmatimonadetes in the H3B treatment. The relative abundances of Acidobacteria and Proteobacteria in the H0B treatment increased by $16.88 \%$ and $11.58 \%$, respectively, and the relative abundances of Acidobacteria and Gemmatimonadetes in the H2J treatment increased by $10.48 \%$ and $0.39 \%$, respectively, compared with those in the H2T treatment. The relative abundances of Acidobacteria and Gemmatimonadetes in the H3J treatment also increased by $20.83 \%$ and $6.12 \%$, respectively, compared with that in the $\mathrm{H} 3 \mathrm{~T}$ treatment (Fig. 3 C).

Cotton straw biochar and compound Bacillus biofertilizer modulate soil bacterial metabolic functions in Cd-stressed soil In addition to the changes of soil bacterial community, the metabolic functions of soil bacteria can also be used to evaluate the improvement of soil Cd pollution. Cotton straw biochar and compound Bacillus biofertilizer treatment increased the abundance values of most bacterial metabolic functions (Fig. 5). Compared with the HOT treatment, HOB and
$\mathrm{H} 0 \mathrm{~J}$ treatments increased the bacteria metabolic function of top 15. Compared with the H1T treatment, H1B and $\mathrm{H} 1 \mathrm{~J}$ treatments increased the biosynthesis of amino acids, ribosome, aminoacyl-tRNA biosynthesis. Compared with the $\mathrm{H} 2 \mathrm{~T}$ treatment, $\mathrm{H} 2 \mathrm{~B}$ and $\mathrm{H} 2 \mathrm{~J}$ treatments increased the microbial metabolism in diverse environments, biosynthesis of amino acids, carbon metabolism, $\mathrm{ABC}$ transporters, quorum sensing, pyruvate metabolism, carbon fixation pathways in prokaryotes, glyoxylate and dicarboxylate metabolism. Compared with the H3T treatment, $\mathrm{H} 3 \mathrm{~B}$ and $\mathrm{H} 3 \mathrm{~J}$ treatments increased the ribosome. Among them, the improvement effect of compound Bacillus biofertilizer on bacterial metabolic function was better than that of cotton straw biochar under different concentrations of $\mathrm{Cd}$ pollution.

\section{Relationship between soil microbial diversity and biochemical properties}

Redundancy analysis (RDA) revealed the relationship between soil microbial community diversity and soil biochemical properties (Fig. $6 \mathrm{~A}$ ). The first principal component of RDA accounted for $46.52 \%$ of the total variation, and the second principal component accounted for $26.49 \%$ of the total variation. So, all variables could be well explained. The results showed that soil biochemical properties $(\mathrm{pH}, \mathrm{C} / \mathrm{N}$ ratio, and soil enzyme activity) and the relative abundances of Acidobacteria and Proteobacteria were closely in the first quadrant, indicating that the relative abundances of Acidobacteria and Proteobacteria were greatly impacted by soil biochemical properties. In the third quadrant, the longest arrow for soil available $\mathrm{Cd}$ concentration indicated that soil available $\mathrm{Cd}$ concentration had the greatest impact on soil microbial diversity. Soil available $\mathrm{Cd}$ had a large angle with soil biochemical properties ( $\mathrm{pH}, \mathrm{C} / \mathrm{N}$ ratio, and soil enzyme activity) and the relative abundances of Acidobacteria and Proteobacteria, indicating that soil available $\mathrm{Cd}$ negatively impacted soil biochemical properties and the relative abundances of Acidobacteria and Proteobacteria. $\mathrm{H} 3 \mathrm{~B}$ and $\mathrm{H} 2 \mathrm{~B}$ treatments were also closely located in the third quadrant, indicating that the bacterial community structure in the $\mathrm{H} 3 \mathrm{~B}$ and $\mathrm{H} 2 \mathrm{~B}$ treatments were similar.

To determine the main factors responsible for the change of microbial community structure and available $\mathrm{Cd}$ concentration in $\mathrm{Cd}$-contaminated soil, the direct and indirect effects of soil biochemical properties (soil enzyme and $\mathrm{pH}$ ) and microbial diversity on soil available $\mathrm{Cd}$ were determined using structural equation model (SEM) (Fig. 6B). The results showed that soil urease and alkaline phosphatase activities had negative correlations 


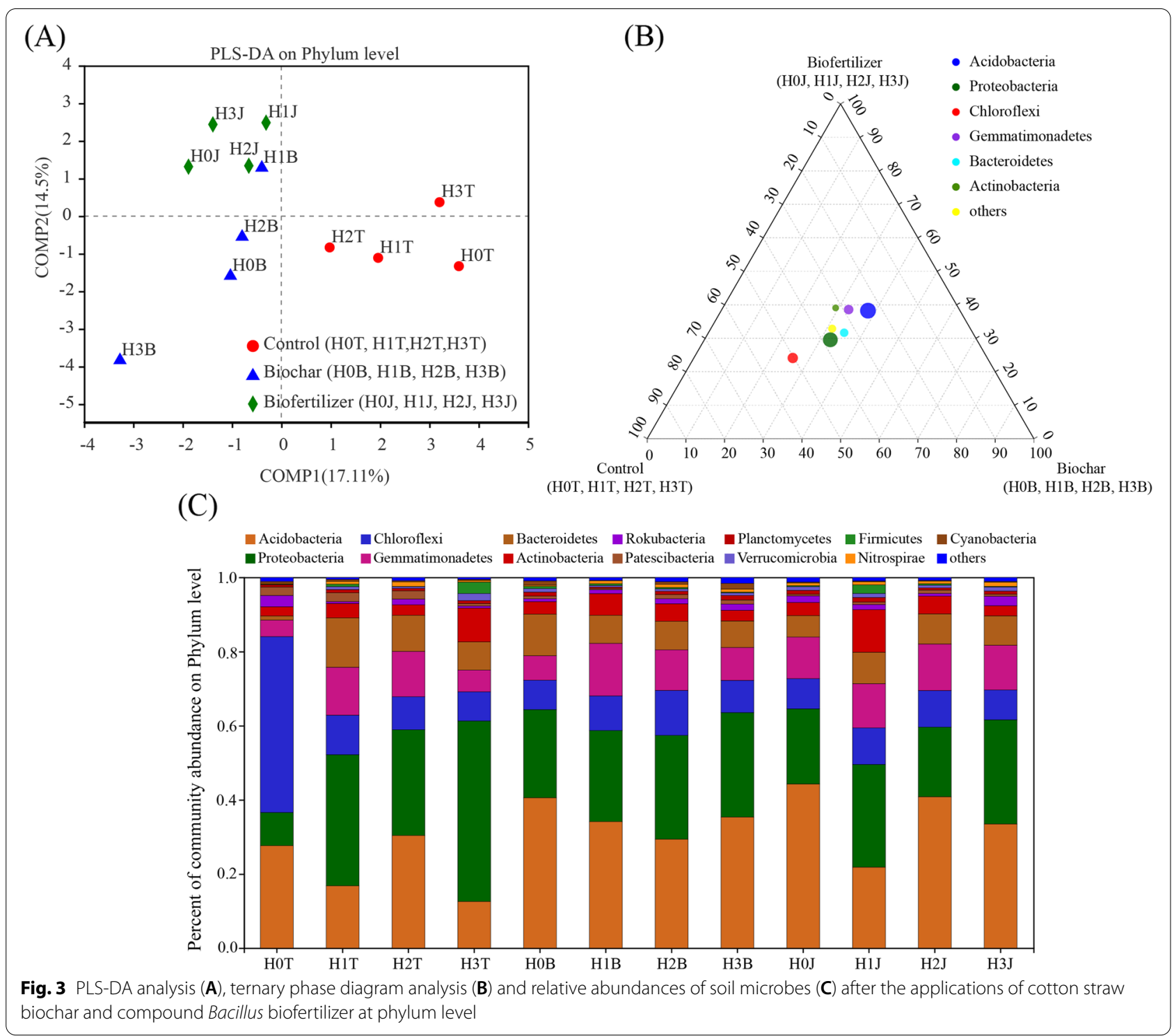

with soil available $C d(\beta=-0.752$ and $\beta=-0.757, P<$ 0.001 ), indicating that soil available $C d$ could suppress soil urease and alkaline phosphatase activities. Soil available $\mathrm{Cd}$ had negative correlation with microbial diversity $(\beta=-0.743, P<0.001)$, indicating that exogenous $\mathrm{Cd}$ could decrease soil microbial diversity. However, urease activity had positive correlation with soil microbial diversity $(\beta=-0.829$ and $\beta=-0.757, P<0.001)$, indicating that soil urease activity could increase soil microbial diversity.

\section{Discussions}

The effects of cotton straw biochar and compound Bacillus biofertilizer on soil biochemical properties was evaluated in this study, and the relationships between $\mathrm{Cd}$ and soil biochemical properties were also measured. Previous studies have shown that the bioavailability of $\mathrm{Cd}$ in the soil may increase when soil $\mathrm{pH}$ decreases; while the soil adsorption of $\mathrm{Cd}$ may increase when soil $\mathrm{pH}$ increases $[28,29]$. In this study, soil $\mathrm{pH}$ and EC increased after the application of cotton straw biochar, which is consistent with the results of Bandara et al. [18]. The increase of soil $\mathrm{pH}$ may be due to the conversion of basic cations (such as $\mathrm{Ca}, \mathrm{Mg}, \mathrm{K}$, and $\mathrm{Na}$ ) in biochar into oxides, hydroxyl oxides, and carbonates (ash), which adhere to biochar during pyrolysis $[24,30]$. The dissolution of the alkaline substances and the application of compound Bacillus biofertilizer could also increase soil $\mathrm{pH}$. In this study, soil $\mathrm{pH}$ increased by 0.95 unit after the application of compound Bacillus biofertilizer, which is consistent with the results of Blaya et al. [31]. It may be due to the high $\mathrm{pH}$ 


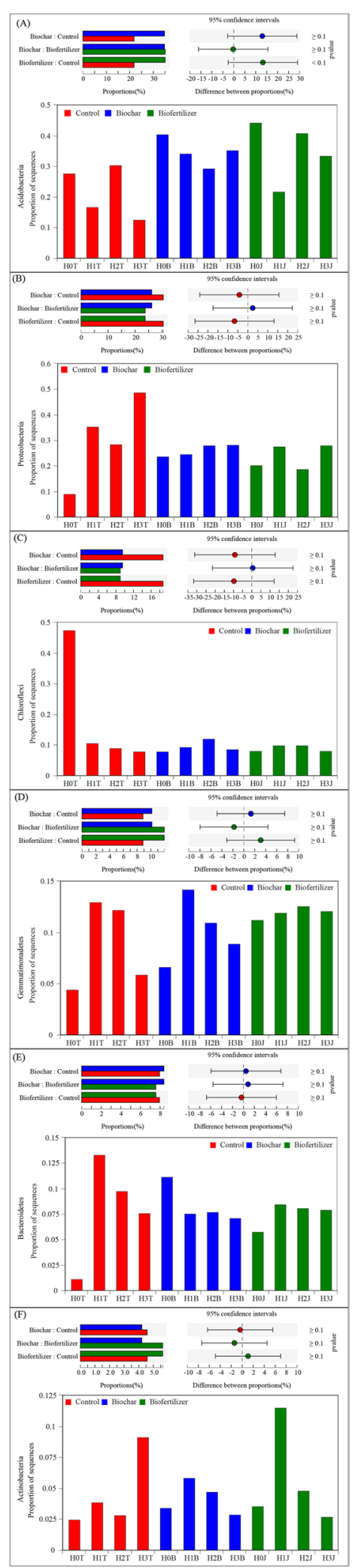

Fig. 4 Analysis of significant differences between groups of dominant phyla in different treatments. Abbreviations: The relative abundances of Acidobacteria (A), Proteobacteria (B), Chloroflexi (C), Gemmatimonadetes $(\mathbf{D})$, Bacteroidetes $(\mathbf{E})$, and Actinobacteria $(\mathbf{F})$ under the comparison among biochar treatments ( $\mathrm{HOB}, \mathrm{H} 1 \mathrm{~B}, \mathrm{H} 2 \mathrm{~B}$, and $\mathrm{H} 3 \mathrm{~B})$, biofertilizer treatments $(\mathrm{HOJ}, \mathrm{H} 1 \mathrm{~J}, \mathrm{H} 2 \mathrm{~J}$, and $\mathrm{H} 3 \mathrm{~J})$, and control $(\mathrm{HOT}, \mathrm{H} 1 \mathrm{~T}$, $\mathrm{H} 2 \mathrm{~T}$, and $\mathrm{H} 3 \mathrm{~T}$ )

of the compound Bacillus biofertilizer. Besides, biochar could accelerate the dissolution of most salts in the soil [18], resulting in the increase of soil electrical conductivity (EC) [32]. The increase of soil EC after the application of compound Bacillus biofertilizer may be due to the interaction of compound Bacillus biofertilizer with inorganic and organic ions in the soil [33]. Moreover, ElKherbawy et al. [34] have showed that the concentration of available $\mathrm{Cd}$ in the soil with $\mathrm{pH}$ greater than 7.2 was lower than that in the acid soil, indicating that a high soil $\mathrm{pH}$ could positively impact $\mathrm{Cd}$ fixation, and soil $\mathrm{pH}$ could increase after the application of biochar [35]. In this study, the soil available $\mathrm{Cd}$ concentration decreased after the application of cotton straw biochar $(P<0.05) . \mathrm{Cd}$ ions precipitate with the alkaline ions in the soil, which reduces the soil available $\mathrm{Cd}$ [16]. The oxygen-containing functional groups of cotton straw biochar (carboxyl, carbonyl, and ester) (Table 3) induce Cd fixation, and absorb $\mathrm{Cd}$ on the surface through surface complexation [36]. Bacillus subtilis in compound Bacillus biofertilizer is a gram-positive, rod-shaped, and aerobic bacterium in the soil. Due to the different cell wall structures, Bacillus subtilis is more likely to bind with metals than gram-negative bacterium. Teichoic acid associated with the cell wall is unique to gram-positive cells, and its phosphate group is a key component of metal uptake [2,37]. In this study, the soil available $\mathrm{Cd}$ concentration decreased by $74.34 \%$ $(P<0.05)$ after the application of compound Bacillus biofertilizer with Bacillus as the main component (Fig. 1). This is mainly because compound Bacillus biofertilizer is rich in a large number of microbes, which can reduce the available $\mathrm{Cd}$ concentration in the soil through the combination with microbial cell walls [38].

Soil enzyme activity is an important biological indicator to evaluate soil quality, especially to the evaluation of soils contaminated by heavy metals [39]. The urease, alkaline phosphatase, and catalase are the most sensitive to heavy metals $[2,40]$. Microorganisms secrete large amounts of urease. The decomposition of urease and the formation of bicarbonate, ammonium, and hydroxyl ions could increase the $\mathrm{pH}$. All the urease-producing isolates could increase the $\mathrm{pH}$ of medium, which may greatly impact the bioavailability of soil heavy metals [2]. The reason for the decrease of soil enzyme activity after the application of exogenous $\mathrm{Cd}$ is that the molecular 


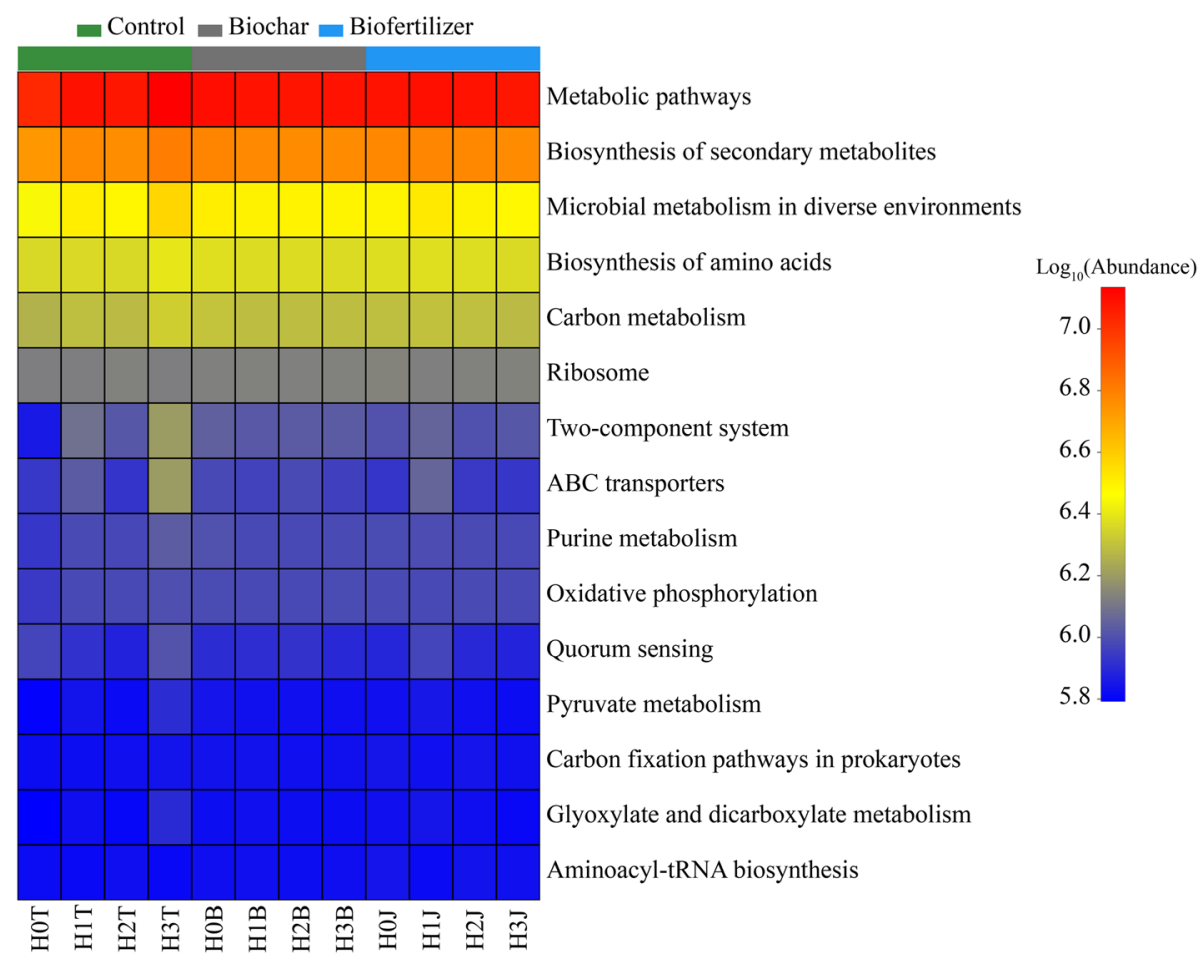

Fig. 5 Effects of cotton straw biochar and compound Bacillus biofertilizer on the relative abundance of predicted bacterial metabolic functions
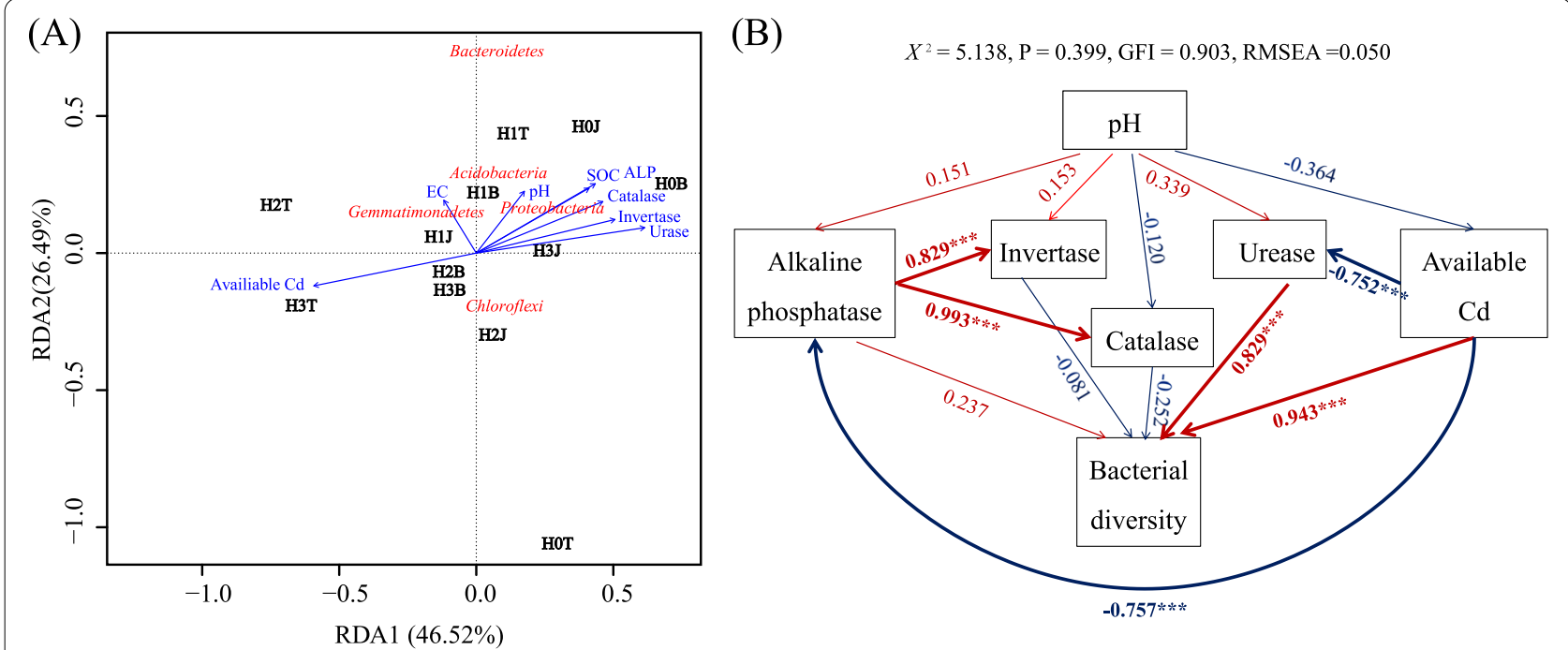

Fig. 6 RDA analysis (A) and structural equation modeling (SEM) (B) between soil biochemical properties and soil microbial structure at phylum level. Abbreviations: soil available Cd, available $\mathrm{Cd}$; $\mathrm{pH}$, soil pH; Urase, soil urase activity; Sucrase, soil sucrase activity; Catalase, soil catalase activity; ALP, soil alkaline phosphatase activity. Blue lines indicate negative relationships, while red lines indicate positive relationships. The microbial diversities are represented by the Chao 1 and Simpson indexes based on the rarified same sequencing depth. The width of arrows indicates the relevance of significant standardized path coefficients $(P<0.05)$. ${ }^{* *} P<0.001,{ }^{* *} P<0.01$

reaction between heavy metals and enzyme-substrate complexes or protein active groups denatures enzyme protein and reduces enzyme activity $[41,42]$. Yang et al.
[43] have shown that soil urease, alkaline phosphatase, and catalase activities could be increased after the application of cotton straw biochar $(P<0.05)$. In this study, 
soil urease, phosphatase, catalase, and sucrase activities increased by $16.55 \%, 15.51 \%, 31.33 \%$, and $24.50 \%$, respectively $(P<0.05)$, after the application of cotton straw biochar. It may be due to that the application of cotton straw biochar improves the soil biochemical properties, creating a good soil micro-environment for soil microbes' growth and metabolism. Thereby, soil enzyme activities are increased [44, 45]. Compound Bacillus biofertilizer also increased soil enzyme activity in this study [46]. The increase in soil enzyme activities may be attributed to the increase in soil organic matter brought by the applications of compound Bacillus biofertilizer and cotton straw biochar. High concentration of soil organic carbon could stimulate soil microbial activities and the secretion of enzymes [46, 47]. In this study, soil alkaline phosphatase and urease activities had a negative correlation with soil available $C d$ concentration $(P<0.01)$ (Fig. 6), indicating that the applications of compound Bacillus biofertilizer and cotton straw biochar could increase soil enzyme activity, thus increasing the fertility and quality of $\mathrm{Cd}$ contaminated soil.

Heavy metal stress not only negatively impacts soil biochemical properties, but also causes changes in composition, activity and function of soil microbial communities [48]. In this study, the application of $\mathrm{Cd}$ reduced the relative abundance of Chloroflexi, and increased the relative abundance of Proteobacteria (Fig. 3 C), they are the core bacteria in control group (Fig. 4). It may be due to the difference in the absorption of heavy metals by soil microbes [49]. Besides, the soil carbon and nitrogen cycle were the main factor affecting soil microbial community [50]. The range of soil $\mathrm{C} / \mathrm{N}$ ratio of $3.5-19.5$ is the most beneficial for the growth and composition of soil microbes [51]. Cotton straw biochar and compound Bacillus biofertilizer are rich in organic matter and nutrients [25], which could provide energy for soil microbial activities, thereby increasing soil microbial abundance and biomass [36, 45, 51]. When cotton straw biochar and compound Bacillus biofertilizer are applied to the soil, the concentration of carbon and nitrogen required by the growth of soil microbes are greatly increased $[52,53]$. In this study, the $\mathrm{C} / \mathrm{N}$ ratio of soil was $16.41-18.66$ after the applications of cotton straw biochar and compound Bacillus biofertilizer (Table 1), indicating that it was a favorable condition for microbial community. Besides, the application of cotton straw biochar increased soil microbial diversity (Table 2) and the relative abundance of Acidobacteria (Fig. 3), Bacteroidetes are the core bacteria in cotton straw biochar group (Fig. 4). Compared with the treatments without modifier, the application of cotton straw biochar obviously impacted the bacterial diversity and functions associated with soil carbon metabolism in Cd-contaminated soil, it may be due to the increase of soil $\mathrm{C} / \mathrm{N}$ ratio caused by the high nutrient concentration of biochar [5, 54]. Moreover, the variations in soil microbial community structure may also be due to the reduction of soil available $\mathrm{Cd}$ concentration (Fig. 6). Acidobacteria, Gemmatimonadetes, Actinobacteria are core bacteria in compound Bacillus biofertilizer group (Fig. 4). Study have found that the number of soil bacteria increases from 18 to $9.8 \times 10^{7} \mathrm{CFU} \cdot \mathrm{g}^{-1}$ after the application of compound Bacillus biofertilizer [25], which is similar to the results of our study. In this study, the $\mathrm{Cd}$ ions in the soil were adsorbed and fixed by core bacteria after the applications of cotton straw biochar and compound Bacillus biofertilizer, thereby the $\mathrm{Cd}$ toxicity could be reduced and the microbial diversity could also be changed. The dominant phylum (Proteobacteria and Cyanobacteria) in the soil is related to specific soil enzyme. These microbes absorb heavy metal ions in the contaminated soil. Thus, the soil enzymes activity and bacterial metabolic functions could be increased (biosynthesis of amino acids and ribosome) (Fig. 5), and the soil quality could be improved $[7,55]$.

\section{Conclusions}

In this study, the application of cotton straw biochar and compound Bacillus biofertilizer could improve soil $\mathrm{pH}$, $\mathrm{EC}, \mathrm{C} / \mathrm{N}$ ratio, soil enzyme activity, as well as the relative abundance and metabolic function of Acidobacteria, Gemmatimonadetes, and Bacillus, while reduce the soil available Cd by $60.24 \%$ and $74.34 \%$, respectively through adsorption. Besides, the key bacteria in cotton straw biochar (Bacteroidetes) and the Bacillus in compound Bacillus biofertilizer (Acidobacteria, Gemmatimonadetes, and Actinobacteria) also play a positive role in the immobilization of Cd. In general, compound Bacillus biofertilizer is better than cotton straw biochar in fixing soil $\mathrm{Cd}$ and improving soil environmental quality, which has great

Table 3 Biochemical properties of biochar and soil

\begin{tabular}{lll}
\hline Property & Biochar & Soil \\
\hline $\mathrm{pH}$ & 9.50 & 7.76 \\
Total nitrogen $\left(\mathrm{g} \cdot \mathrm{kg}^{-1}\right)$ & 0.89 & 0.46 \\
Total P $\left(\mathrm{g} \cdot \mathrm{kg}^{-1}\right)$ & 2.54 & 0.82 \\
Organic matter $\left(\mathrm{g} \cdot \mathrm{kg}^{-1}\right)$ & 625 & 14.73 \\
Total $\mathrm{K}\left(\mathrm{g} \cdot \mathrm{kg}^{-1}\right)$ & 8.62 & 246.83 \\
Total Cd $\left(\mathrm{mg} \cdot \mathrm{kg}^{-1}\right)$ & 0.002 & 0.25 \\
Available $\mathrm{Cd}$ & - & 0.121 \\
Total salinity $\left(\mathrm{g} \cdot \mathrm{kg}^{-1}\right)$ & - & 3.36 \\
Carboxyl $\left(\mathrm{mmol} \cdot \mathrm{g}^{-1}\right)$ & 0.20 & - \\
Lactone $\left(\mathrm{mmol} \cdot \mathrm{g}^{-1}\right)$ & 0.25 & - \\
Phenolic hydroxyl $\left(\mathrm{mmol} \cdot \mathrm{g}^{-1}\right)$ & 0.21 & - \\
\hline
\end{tabular}


potential for the remediation of Cd-contaminated alkaline soils in arid and semi-arid areas.

\section{Methods}

\section{Experimental site}

This study was conducted at the Experimental Station of Agricultural College of Shihezi University, Xinjiang Province, China $\left(44^{\circ} 18^{\prime} 42.37^{\prime \prime} \mathrm{N}, 86^{\circ} 03^{\prime} 20.72^{\prime \prime} \mathrm{E}\right)$, where there has a temperate arid continental climate. The average annual temperature is $7.5-8.2{ }^{\circ} \mathrm{C}$. The annual sunshine duration is $2318-2732 \mathrm{~h}$, the frost-free period is $147-191 \mathrm{~d}$, the annual rainfall is $180-270 \mathrm{~mm}$, and the annual evaporation is 1000 - $1500 \mathrm{~mm}$ [27]. The soil texture is sandy loam.

\section{Preparation of experimental materials}

Soils were collected from the cotton field with twentyfive years of continuous cropping in the study area. After removing residues, soils were air-dried and sieved through $2 \mathrm{~cm}$ and $0.19 \mathrm{~mm}$ sieves to determine soil physical and chemical properties (Table 3). Solid $\mathrm{CdCl}_{2} \cdot 5 \mathrm{H}_{2} \mathrm{O}$ was mixed with the soil to prepare soil samples with different $\mathrm{Cd}$ concentrations. Solution $\left(1.2 \mathrm{~g} \cdot \mathrm{L}^{-1}\right.$ of $\left.\mathrm{Cd}^{2+}\right)$ of $10 \mathrm{~mL}, 20 \mathrm{~mL}$, and $40 \mathrm{~mL}$ were mixed with $12 \mathrm{~kg}$ soil to prepare the soil samples with $0.25(\mathrm{H} 0), 1(\mathrm{H} 1), 2(\mathrm{H} 2)$, and $4(\mathrm{H} 3) \mathrm{mg} \cdot \mathrm{kg}^{-1}$ exogenous $\mathrm{Cd}^{2+}$. These levels were equivalent to three, six, and eleven times of the average soil Cd concentration globally [56, 57]. Finally, soil samples were stored for $60 \mathrm{~d}$ for subsequent tests [58].

Cotton straw biochar was prepared using anaerobic pyrolysis of cotton straw at $450{ }^{\circ} \mathrm{C}$ for $6 \mathrm{~h}$, with a resultant biochar conversion rate of $37.5 \%$. Cotton-straw biochar (B) was prepared using cotton stalk according to [59]. Cotton straw biochar was air-dried and sieved through a $0.2 \mathrm{~mm}$ sieve, and then the biochemical properties, including $\mathrm{pH}$, organic matter, total nitrogen, total phosphorus, and total potassium, were measured [20]. Dried cotton straw biochar of $0.5 \mathrm{~g}$ was accurately weighed and digested with a mixture of nitric acid and muriatic acid ( $v: v=1: 3)$ (Guaranteed reagent). The Cd concentration of cotton straw biochar was determined using the Hitachi Z2000 graphite atomic absorption spectrophotometer (PinAAcle900T, PerkinElmer, USA) (Table 3). The compound Bacillus biofertilizer (J) containing dominant functional bacteria of Bacillus was purchased from Shandong lvlong Biotechnology Co., Ltd, China, and the biochemical properties were measured according to the Standards of Microbial Inoculants in Agriculture (SMIA, National Standard of China, GB20287-2006). Compound Bacillus biofertilizer was sieved through a $0.2 \mathrm{~mm}$ sieve. The Colony-Forming Units (CFU) was greater than or equal to 20 billion $\cdot \mathrm{g}^{-1}$, and the miscellaneous bacteria rate was less than $0.4 \%$. The moisture was less than $10 \%$, and $\mathrm{pH}$ was 7.8. Total Cd concentration was $0.0001 \mathrm{mg} \cdot \mathrm{L}^{-1}$, total nitrogen concentration was $900 \mathrm{mg} \cdot \mathrm{L}^{-1}$, and total organic carbon concentration was $3791 \mathrm{mg} \cdot \mathrm{L}^{-1}$.

\section{Experimental design}

The experiment employed a randomized block design with two factors. Four levels of soil $\mathrm{Cd}$ concentration were set, which were $0.25(\mathrm{H} 0), 1(\mathrm{H} 1), 2(\mathrm{H} 2)$, and $4(\mathrm{H} 3)$ $\mathrm{mg} \cdot \mathrm{kg}^{-1}$, and two modifiers were applied ( $\mathrm{T}$ means no modifier). There were twelve treatments in total, and each treatment had five replicates (Table 4). Cd-contaminated soil $(12 \mathrm{~kg})$ was mixed with $3 \%(\mathrm{w} / \mathrm{w})$ cotton straw biochar and $1.5 \%(\mathrm{w} / \mathrm{w})$ compound Bacillus biofertilizer separately, and transferred into ceramic pots with a height of $40 \mathrm{~cm}$ and a diameter of $25 \mathrm{~cm}$. After that, they were stored in a greenhouse $\left(25{ }^{\circ} \mathrm{C}\right)$ for one week. Soils were irrigated with deionized water to keep the water holding capacity at $60 \%$. Rhizosphere soil samples were collected after 120 days of cultivation. Part of the soil samples was air-dried for the analysis of soil $\mathrm{pH}$, enzymes, total $\mathrm{Cd}$ concentration, and available $\mathrm{Cd}$ concentration; the other was sieved through a $2 \mathrm{~mm}$ sieve and stored at $-80^{\circ} \mathrm{C}$ for microbial diversity analysis.

\section{Determination of soil indices Soil biochemical indices}

Soil $\mathrm{pH}$ was measured with a $\mathrm{pH}$ meter (Thermo Orion 920 A, Thermo Orion, USA) (soil: water $=1: 5$ ). Soil organic carbon was measured with the wet oxidation method [60]. Soil total nitrogen concentration was measured with a semi-micro-Kjeldahl procedure [18]. Soil available $\mathrm{Cd}$ concentration was measured with the diethylenetriaminepentaacetic acid (DTPA) extraction method using a graphite furnace atomic absorption spectrophotometer (Z2000, Hitachi, Tokyo, Japan) [18]. Soil urease activity was measured with indophenol-blue colorimetry, invertase activity was measured using 3,5-dinitrosalicylic acid colorimetry, alkaline phosphatase activity of disodium phenyl phosphate was measured using colorimetric method, and soil catalase activity was determined using the volumetric method [18].

To determine the water holding capacity, damp soil of $50 \mathrm{~g}$ was accurately weighed and transferred into the tube with mesh base $(3.5 \mathrm{~cm}$ in diameter and $5 \mathrm{~cm}$ in length). Then, the tube was placed in a container with water and allowed to be wetted by capillary action. When the soil surface became glossy, soil cores were removed from the water and allowed to drain until they stopped dripping. The soil in the cores was then gently removed and weighed. The water holding capacity of the soil was determined as the weight of water held in the soil cores 
compared with the oven-dry weight $\left(105^{\circ} \mathrm{C}\right)$ of the sample $[61,62]$.

\section{Analyses of the structure and diversity of soil microbial community}

DeoxyriboNucleic Acid (DNA) was extracted from soil samples using the E.Z.N.A. ${ }^{\circledR}$ Soil DNA Kit (OMEGA, USA). Soil samples stored at $-80{ }^{\circ} \mathrm{C}$ were weighed to extract the total DNAs according to the instructions of the kit. After that, the DNAs were stored at $-80{ }^{\circ} \mathrm{C}$. Polymerase Chain Reaction (PCR) amplification was conducted using $0.8 \mu \mathrm{L}$ of bacterial synthetic primers (Forward Primer: ACTCCTACGGGAGGCAGCAG; and Reverse Primer: GGACTACHVGGGTWTCTAAT). $16 \mathrm{~S}$ rRNA gene V3-V4 was targeted using the primer set. The product was cycled 30 times at $95{ }^{\circ} \mathrm{C}$. The PCR products were detected using $2 \%$ agarose gel electrophoresis, and then AxyPrep DNA Gel Extraction Kit and Quantus ${ }^{\text {тм }}$ Fluorometer were used to purify and quantify the products [63]. Illumina MiSeq System (Milq PE300 platform of Illumina compan, USA) was used for sequencing by Shanghai Meiji Technologies Corporation, China.

\section{Data process and analysis}

Data of soil available $\mathrm{Cd}$ and $\mathrm{pH}$ were subjected to regression analysis using a Duncan test at $P<0.05$ (SPSS 18.0). Redundancy analysis (RDA) was used to evaluate the effect of soil biochemical variables on the microbial community composition based on a Bray-Curtis distance matrix. The Pearson's correlation test was used to examine the correlation between the relative abundance of microbes and environmental factors (soil available $\mathrm{Cd}$, soil $\mathrm{pH}$, and soil enzyme). R software (version 3.6.1) and

Table 4 Amount of $\mathrm{Cd}$, biochar, and biofertilizer in each treatment

\begin{tabular}{llll}
\hline Treatments & $\mathbf{C d}\left(\mathbf{m g} \cdot \mathbf{k g}^{-\mathbf{1}}\right)$ & Biochar (\%) & Biofertilizer (\%) \\
\hline HOT & 0.25 & 0 & 0 \\
HOB & 0.25 & $3 \%$ & 0 \\
HOJ & 0.25 & 0 & $1.5 \%$ \\
H1T & 1 & 0 & 0 \\
H1B & 1 & $3 \%$ & 0 \\
H1J & 1 & 0 & $1.5 \%$ \\
H2T & 2 & 0 & 0 \\
H2B & 2 & $3 \%$ & 0 \\
H2J & 2 & 0 & $1.5 \%$ \\
H3T & 4 & 0 & 0 \\
H3B & 4 & $3 \%$ & 0 \\
H3J & 4 & 0 & $1.5 \%$ \\
\hline
\end{tabular}

$\mathrm{T}$, no modifiers; $\mathrm{B}, 3 \%$ biochar was applied; J, 1.5\% biofertilizer was applied; $\mathrm{HO}$, no $\mathrm{Cd} ; \mathrm{H} 1,1 \mathrm{mg} \cdot \mathrm{kg}^{-1}$ of $\mathrm{Cd}$ was applied; $\mathrm{H2}, 2 \mathrm{mg} \cdot \mathrm{kg}^{-1}$ of $\mathrm{Cd}$ was applied; $\mathrm{H} 3$, $4 \mathrm{mg} \cdot \mathrm{kg}^{-1}$ of Cd was applied
Origin 8.0 software (Origin Lab, Massachusetts, USA) were used for plotting.

Sequences were clustered at a 97\% similarity level using Quantitative Insights Into Microbial Ecology (QIIME) package (version 1.9.1), and operational taxonomic units (OTU) were obtained, with $0.005 \%$ as threshold. To compare the species richness of soil bacteria after applying cotton straw biochar and compound Bacillus biofertilizer, the total community richness was calculated using different statistical methods, including Chao1, Simpson, and Coverage indices. Phylogenetic Investigation of Communities by Reconstruction of Unobserved States (PICRUSt2) software (https://github.com/picrust/picru st2/wiki) predicted the functions (MetaCyc database) of soil bacteria. The structural equation model (SEM) analysis was performed using AMOS 20.0 software (AMOS, IBM, USA) with a maximum-likelihood method [35].

\section{Acknowledgements}

Not applicable.

\section{Authors' contributions}

YQZ and HJW conceived and designed the study; WDL carried out the field and laboratory work and bioinformatic analyses. YQZ drafted the manuscript; $J H S$ and $X \mathrm{~L}$ coordinated the study and helped draft the manuscript. All authors gave final approval for publication and agree to be held accountable for the work performed therein.

\section{Funding}

This work was supported by the National Natural Science Foundation of China (Grant No. 31360301) and the International Cooperation Project of the Ministry of Science and Technology (2015DFA11660) and Major Science and Technology Project of the XPCC (2018AA004, 2018AA005, 2020AB018).

\section{Availability of data and materials}

The datasets used and/or analysed during the current study available from the corresponding author on reasonable request.

\section{Declarations}

Ethics approval and consent to participate

Not applicable.

\section{Consent for publication}

Not applicable.

\section{Competing interests}

No potential conflict of interest was reported by the authors.

Received: 28 September 2021 Accepted: 10 January 2022

Published online: 26 January 2022

References

1. Heidar M, Darijani T, Alipour V. Heavy metal pollution of road dust in a city and its highly polluted suburb; quantitative source apportionment and source-specific ecological and health risk assessment. Chemosphere. 2021; 273: 129656. https://doi.org/10.1016/j.chemosphere.2021.129656.

2. Tauqeer HM, Fatima M, Rashid A, Shahbaz AK, Ramzani PMA, Farhad M, et al. The current scenario and prospects of immobilization remediation technique for the management of heavy metals contaminated soils. In: Hasanuzzaman M. (eds) Approaches to the Remediation of Inorganic 
Pollutants. Springer, Singapore. 2021; 155-185. https://doi.org/10.1007/ 978-981-15-6221-1_8.

3. Fu YH, Li FM, Guo SH, Zhao MY. Cadmium concentration and its typical input and output fluxes in agricultural soil downstream of a heavy metal sewage irrigation area. J Hazard Mater. 2021; 412: 125203. https://doi.org/ 10.1016/j.jhazmat.2021.125203.

4. Tauqeer HM, Karczewska A, Lewińska K, Fatima M, Khan SA, Farhad M, et al. Chapter 36 - Environmental concerns associated with explosives (HMX, TNT, and RDX), heavy metals and metalloids from shooting range soils: Prevailing issues, leading management practices, and future perspectives. Handbook of Bioremediation. 2021; 569-590. https://doi.org/ 10.1016/B978-0-12-819382-2.00036-3.

5. Iftikhar S, Turan V, Tauqeer HM, Rasool B, Zubair M, Rahman M, et al. Chapter 5 - Phytomanagement of as-contaminated matrix: Physiological and molecular basis. 2021; 61-79. https://doi.org/10.1016/B978-0-12-8193822.00005-3.

6. Nahar K, Ali MM, Khanom A, Alam MK, Rahman MM. Levels of heavy metal concentrations and their effect on net nitrification rates and nitrifying archaea/bacteria in paddy soils of Bangladesh. Appl Soil Ecol. 2020; 156: 103697. https://doi.org/10.1016/j.apsoil.2020.103697.

7. Zeng P, Guo Z, Xiao X, Peng C. Effects of tree-herb co-planting on the bacterial community composition and the relationship between specific microorganisms and enzymatic activities in metal (loid)-contaminated soil. Chemosphere. 2019; 220: 237-248. https://doi.org/10.1016/j.chemo sphere.2018.12.073.

8. An MJ, Chang DD, Hong DS, Fan H, Wang KY. Metabolic regulation in soil microbial succession and niche differentiation by the polymer amendment under cadmium stress. J Hazard Mater. 2021; 416(8): 126094. https://doi.org/10.1016/j.jhazmat.2021.126094.

9. Wang J, LuY, Shen G. Combined effects of cadmium and butachlor on soil enzyme activities and microbial community structure. Environ Geol. 2007; 51: 1221-1228. https://doi.org/10.1007/s00254-006-0414-y.

10. Harris J. Soil Microbial communities and restoration ecology: facilitators or followers? Science. 2009; 325, 573-574. https://doi.org/10.1126/scien ce.1172975.

11. Fritze H, Perkiomaki J, Saarela U. Effect of Cd-containing wood ash on the microflora of coniferous forest humus. Fems Microbiol Ecol. 2000; 32: 43-51. https://doi.org/10.1111/j.1574-6941.2000.tb00697.x.

12. Choi A, Wang S, Lee M. Biosorption of cadmium, copper, and lead ions from aqueous solutions by Ralstonia sp. and Bacillus sp. isolated from diesel and heavy metal contaminated soil. Geosci J. 2009; 13: 331-341. https://doi.org/10.1007/s12303-009-0031-3.

13. Kamal $S$, Prasad R, Varma A. Soil microbial diversity in relation to heavy metals. Soil Heavy Metals. 2010; 19: 31-63. https://doi.org/10.1007/ 978-3-642-02436-8_3.

14. Turan V. Potential of pistachio shell biochar and dicalcium phosphate combination to reduce $\mathrm{Pb}$ speciation in spinach, improved soil enzymatic activities, plant nutritional quality, and antioxidant defense system. Chemosphere. 2020; 245: 125611. https://doi.org/10.1016/j.chemo sphere.2019.125611.

15. Turan V. Confident performance of chitosan and pistachio shell biochar on reducing Ni bioavailability in soil and plant plus improved the soil enzymatic activities, antioxidant defense system and nutritional quality of lettuce. Ecotoxicol Environ Saf. 2019; 183: 10594. https://doi.org/10. 1016/j.ecoenv.2019.109594.

16. Turan V, Ramzani PMA, Ali Q, Abbas F, Iqbal M, Irum A, et al. Alleviation of nickel toxicity and an improvement in zinc bioavailability in sunflower seed with chitosan and biochar application in $\mathrm{pH}$ adjusted nickel contaminated soil. Arch Agron Soil Sci. 2018; 64(8)1053-1067:https://doi. org/1053-1067.10.1080/03650340.2017.1410542.

17. Turan V, Khan SA, Rahman M, lqbal M, Ramzani PMA, Fatima M, et al. Promoting the productivity and quality of brinjal aligned with heavy metals immobilization in a wastewater irrigated heavy metal polluted soil with biochar and chitosan. Ecotoxicol Environ Saf. 2018; 161: 409-419. https:// doi.org/10.1016/j.ecoenv.2018.05.082.

18. Bandara T, Herath I, Kumarathilaka P, Hseu Z, Ok YS Vithanage M. Efficacy of woody biomass and biochar for alleviating heavy metal bioavailability in serpentine soil. Environ Geochem Health. 2017; 39: 391-401. https:// doi.org/10.1007/s10653-016-9842-0.

19. Liu G, Xie M, Zhang S. Effect of organic fraction of municipal solid waste (OFMSW)-based biochar on organic carbon mineralization in a dry land soil. J Mater Cycles Waste Manage. 2017; 19: 473-482. https://doi.org/10. 1007/s10163-015-0447-y.

20. Sun CX, Chen LJ, Wu ZJ, Zhou LK, Shimizu H. Soil persistence of Bacillus thuringiensis (Bt) toxin from transgenic Bt cotton tissues and its effect on soil enzyme activities. Biol Fertil Soils. 2007; 43: 617-620. https://doi.org/ 10.1007/s00374-006-0158-6.

21. Vassilev N, Vassileva M, Lopez A, Martos V, Reyes A, Maksimovic I, et al. Unexploited potential of some biotechnological techniques for biofertilizer production and formulation. Appl Microbiol Biotechnol. 2015; 99: 4983-4996. https://doi.org/10.1007/s00253-015-6656-4.

22. Zouboulis Al, Loukidou MX, Matis KA. Biosorption of toxic metals from aqueous solutions by bacteria strains isolated from metal-polluted soils. Process Biochem. 2004; 39: 909-916. https://doi.org/10.1016/S00329592(03)00200-0.

23. Chen J, Chen D, Xu Q, Fuhrmann J, Li L, Pan G. et al. Organic carbon quality, composition of main microbial groups, enzyme activities, and temperature sensitivity of soil respiration of an acid paddy soil treated with biochar. Biol Fertil Soils 2019; 55, 185-197. https://doi.org/10.1007/ s00374-018-1333-2.

24. Ahmad M, Moon DH., Vithanage M, Koutsospyros A, Lee SS, Yang JE., et al. Production and use of biochar from buffalo weed (Ambrosia trifida L.) for trichloroethylene removal from water. J Chem Technol Biotechnol. 2014; 89(1): 150-157. https://doi.org/10.1002/jctb.4157.

25. Shang C, Chen A, Chen G, Li H, Guan S, He J. Microbial biofertilizer decreases nicotine concentration by improving soil nitrogen supply. Appl Microbiol Biotechnol. 2017; 181: 1-14. https://doi.org/10.1007/ s12010-016-2195-4

26. Wang W, Lai Y, Ma Y, Liu Z, Wang S, Hong C. Heavy metal contamination of urban topsoil in a petrochemical industrial city in Xinjiang, China J Arid Land. 2016; 8: 871-880. https://doi.org/CNKI:SUN:GHKX.0.2016-06-005.

27. Mamut A, Eziz M, Mohammad A. Pollution and ecological risk assessment of heavy metals in farmland soils in Yanqi County, Xinjiang, northwest China. Eurasian Soil Sci. 2018; 51: 985-993. https://doi.org/10.1134/S1064 229318080082

28. Ardestani MM, Van GCA. Sorption and $\mathrm{pH}$ determine the long-term partitioning of cadmium in natural soils. Environ Sci Pollut Res. 2016; 23(18): 18492-18501. https://doi.org/10.1007/s11356-016-7034-1.

29. Yin Z, Song L, Lin Z, Hui K, Wang Q, Song H, Xuan LL, et al. Granular activated carbon-supported titanium dioxide nanoparticles as an amendment for amending copper-contaminated sediments: Effect on the $\mathrm{pH}$ in sediments and enzymatic activities. Ecotoxicol Environ Saf. 2020; 206: 111325. https://doi.org/10.1016/j.ecoenv.2020.111325.

30. Ahmad M, Hashimoto Y, Moon DH, Lee SS, Ok YS. Immobilization of lead in a korean military shooting range soil using eggshell waste: an integrated mechanistic approach. J Hazard Mater. 2012; 209-210: 392-401. https://doi.org/10.1016/j.jhazmat.2012.01.047.

31. Blaya J, Lloret E, Ros M, Pascual JA. Identification of predictor parameters to determine agro-industrial compost suppressiveness against Fusarium oxysporum and Phytophthora capsici diseases in muskmelon and pepper seedlings. J Sci Food Agric. 2015; 95: 1482-1490. https://doi.org/10.1002/ jsfa.6847.

32. Yang X, Liu J, McGrouther K, Huang H, Lu K, Guo X., et al. Effect of biochar on the extractability of heavy metals ( $\mathrm{Cd}, \mathrm{Cu}, \mathrm{Pb}$, and $\mathrm{Zn}$ ) and enzyme activity in soil. Environ Sci Pollut Res. 2016; 23: 974-984. https://doi.org/ 10.1007/s11356-015-4233-0.

33. Iftikhar S, Saleem M, Ahmad KS, Jaffri SB. Synergistic mycoflora-natural farming mediated biofertilization and heavy metals decontamination of lithospheric compartment in a sustainable mode via Helianthus annuus. Int J Environ Sci Technol. 2019; 16: 6735-6752. https://doi.org/10.1007/ s13762-018-02180-8.

34. El-Kherbawy M, Angle JS, Heggo A. Soil pH, rhizobia, and vesicular-arbuscular mycorrhizae inoculation effects on growth and heavy metal uptake of alfalfa (Medicago sativa L.). Biol Fertil Soils. 1989; 8(1): 61-65. https://doi. org/10.1007/bf00260517.

35. Chen L, Jiang Y, Liang C, Luo Y, Xu Q, Han C, et al. Competitive interaction with keystone taxa induced negative priming under biochar amendments. Microbiome. 2019; 7: 150. https://doi.org/10.1186/ s40168-019-0693-7.

36. Li H, Dong X, Silva EB, Oliveira LM, Chen Y, Ma LQ. Mechanisms of metal sorption by biochars: biochar characteristics and modifications. 
Chemosphere. 2017; 178: 466-478. https://doi.org/10.1016/j.chemo sphere.2017.03.072

37. Çolak F, Atar N, Yazıcıoğlu D, Olgun A. Biosorption of lead from aqueous solutions by Bacillus strains possessing heavy-metal resistance. Chem Eng J. 2011; 173(2): 422-428. https://doi.org/10.1016/j.cej.2011.07.084.

38. Li X, Cai Y, Liu D, Ai Y, Zhang M, Gao Y, et al. Occurrence, fate, and transport of potentially toxic metals (PTMs) in an alkaline rhizosphere soil-plant (Maize, Zea mays L.) system: the role of Bacillus subtilis. Environ Sci Pollut Res. 2019; 26: 5564-5576. https://doi.org/10.1007/s11356-018-4031-6.

39. Wang L, Zou R, Li YCC, Tong ZH, You M, Huo WM., et al. Effect of WheatSolanum nigrum L. intercropping on Cd accumulation by plants and soil bacterial community under Cd contaminated soil. Ecotoxicol Environ Saf. 2020; 206: 111383. https://doi.org/10.1016/j.ecoenv.2020.111383

40. Papa S, Bartoli G, Pellegrino A, Fioretto A. Microbial activities and trace element contents in an urban soil. Environ Monit Assess. 2010; 165: 193-203. https://doi.org/10.1007/s10661-009-0938-1.

41. Nannipieri P. The potential use of soil enzymes as indicators of productivity, sustainability and pollution; in soil biota- management in sustainable farming systems. CSIRO, East Melbourne, Victoria, Australia. 1995: 238-244.

42. Xue KD J, Nostrand D, Zhou JZ, Neu S, Renella G. Phytomanagement reduces metal availability and microbial metal resistance in a metal contaminated soil. Front Microbiol. 2020; 11: 1889. https://doi.org/10.3389/ fmicb.2020.01899.

43. Jaiswal AK, Frenkel O, Tsechansky L, Elad Y, Graber ER Immobilization and deactivation of pathogenic enzymes and toxic metabolites by biochar: a possible mechanism involved in soilborne disease suppression. Soil Biol Biochem. 2018; 121: 59-66. https://doi.org/10.1016/j.soilbio.2018.03.001.

44. Palansooriya KN, Wong JF, Hashimoto Y, Huang L, Rinklebe J, Chang $\mathrm{S}$, et al. Response of microbial communities to biochar-amended soils: a critical review. Biochar. 2019; 1: 3-22. https://doi.org/10.1007/ s42773-019-00009-2.

45. Turan V. Arbuscular mycorrhizal fungi and pistachio husk biochar combination reduces Ni distribution in mungbean plant and improves plant antioxidants and soil enzymes. Physiol Plantarum. 2021; 173 (1): 418-429. https://doi.org/10.1111/ppl.13490.

46. Makoi JHJR, Ndakidemi PA. Selected soil enzymes: examples of their potential roles in the ecosystem. Afr J Biotechnol. 2008; 7: 181-191. https://doi.org/10.5897/AJB07.590.

47. Turan V. Calcite in combination with olive pulp biochar reduces Ni mobility in soil and its distribution in chili plant. Int J Phytoremediat. 2021; (4): 1-11. https://doi.org/10.1080/15226514.2021.1929826.

48. Brookes PC. The use of microbial parameters in monitoring soil pollution by heavy metals. Biol Fertil Soils. 1995; 19: 269-279. https://doi.org/10. 1007/bf00336094.

49. Peralta AL, Ludmer S, Kent AD. Hydrologic history influences microbial community composition and nitrogen cycling under experimental drying/wetting treatments. Soil Biol Biochem. 2013; 66: 29-37. https://doi. org/10.1016/j.soilbio.2013.06.019.

50. Ghani A, Sarathchandra U, Ledgard S, Dexter M, Lindsey S. Microbial decomposition of leached or extracted dissolved organic carbon and nitrogen from pasture soils. Biol Fertil Soils. 2013, 49: 747-751. https://doi. org/10.1007/s00374-012-0764-4

51. Liu M, Li Y, Che Y, Deng S, Xiao Y. Effects of different fertilizers on growth and nutrient uptake of Lolium multiflorum grown in Cd-contaminated soils. Environ Sci Pollut Res. 2017; 24: 23363-23370. https://doi.org/10. 1007/s11356-017-9706-X.

52. Palviainen M, Berninger F, Bruckman V J, Köster K, Assumpção C, Aaltonen $\mathrm{H}$, et al. Effects of biochar on carbon and nitrogen fluxes in boreal forest soil. Plant Soil. 2018; 425: 71-85. https://doi.org/10.1007/ s11104-018-3568-y.

53. Hass A, Gonzalez JM, Lima IM, Godwin HW, Halvorson JJ, Boyer DG. Chicken manure biochar as liming and nutrient source for acid Appalachian soil. J Environ Qual. 2012; 41(4): 1096-1106. https://doi.org/10. 2134/jeq2011.0124.

54. Li Q, Xing YN, Fu XW, Ji L, LiTY, Wang J, et al. Biochemical mechanisms of rhizospheric Bacillus subtilis-facilitated phytoextraction by alfalfa under cadmium stress-Microbial diversity and metabolomics analyses. Ecotox Environ Safe. 2021; 212: 112016. https://doi.org/10.1016/j.ecoenv.2021. 112016.
55. Li X, Yao S, Bian YR, Jiang X, Song Y. The combination of biochar and plant roots improves soil bacterial adaptation to PAH stress: Insights from soil enzymes, microbiome, and metabolome. J Hazard Mater. (2020); 400: 123227. https://doi.org/10.1016/j.jhazmat.2020.123227.

56. Adriano DC. Trace elements in terrestrial environments: biogeochemistry, bioavailability and risks of metals. 2nd ed. New York: Springer. 2001.

57. Rawlins BG, McGrath SP, Scheib AJ, Breward N, Cave M, Lister TR, et al. The advanced soil geochemical atlas of England and Wales. British Geological Survey, Keyworth. 2012.

58. Bashir S, Rehman M, Yousaf M, Salam A, Asghar RMA. Comparative efficiency of wheat straw and sugarcane bagasse biochar reduces the cadmium bioavailability to spinach and enhances the microbial activity in contaminated soil. Int J Phytorem. 2019; 1-6. https://doi.org/10.1080/ 15226514.2019.1606781.

59. Lehmann J, Rillig MC, Thies J, Masiello CA, Hockaday WC, Crowley D. Biochar effects on soil biota-a review. Soil Biol Biochem. 2011; 43(9): 1812-1836. https://doi.org/10.1016/j.soilbio.2011.04.022.

60. Shahbaz AK, Ramzani PMA, Saeed R, Turan V, Iabal M, Lewinska K, et al. Effects of biochar and zeolite soil amendments with foliar proline spray on nickel immobilization, nutritional quality and nickel concentrations in wheat. Ecotoxicol Environ Saf. 2019; 173: 182-191. https://doi.org/10. 1016/j.ecoenv.2019.02.025.

61. Hallam J, Hodson ME. Impact of different earthworm ecotypes on water stable aggregates and soil water holding capacity. Biol Fertil Soils 2020; 56: 607-617. https://doi.org/10.1007/s00374-020-01432-5.

62. Guo JX, Zhou YX, Guo HJ, Min W Saline and alkaline stresses alter soil properties and composition and structure of gene-based nitrifier and denitrifier communities in a calcareous desert soil. BMC Microbiology. 2021; 21: 246. https://doi.org/10.1186/s12866-021-02313-z.

63. Chen XH, Hu AQ, Zou Q, Luo S, Wu HT, et al. The Mesorhizobium huakuii transcriptional regulator AbiEi plays a critical role in nodulation and is important for bacterial stress response. BMC Microbiology. 2021; 21: 245. https://doi.org/10.1186/s12866-021-02304-0.

\section{Publisher's Note}

Springer Nature remains neutral with regard to jurisdictional claims in published maps and institutional affiliations.

Ready to submit your research? Choose BMC and benefit from:

- fast, convenient online submission

- thorough peer review by experienced researchers in your field

- rapid publication on acceptance

- support for research data, including large and complex data types

- gold Open Access which fosters wider collaboration and increased citations

- maximum visibility for your research: over $100 \mathrm{M}$ website views per year

At BMC, research is always in progress.

Learn more biomedcentral.com/submissions 